\title{
GAGASAN MULTIKULTURALISME DALAM MATERI MUATAN LOKAL SMP/MTS DI KALIMANTAN BARAT
}

\author{
MULTICULTURALISM IDEAS \\ IN LOCAL MATERIALS OF SMP/MTS \\ IN WEST KALIMANTAN
}

\author{
Valensius Ngardi \\ Mahasiswa Pasca-Sarjana Program Magister Ilmu Religi dan Budaya \\ Universitas Sanata Dharma \\ Jln. Ngadikan No. 1 Kota Baru Yogyakarta 55224 \\ flavingardi@gmail.com
}

Diterima tanggal 2 Maret 2018

Disetujui tanggal 24 Juni 2018

\begin{abstract}
This paper describes how the idea of multiculturalism is integrated into local content that is used as learning materials in junior high schools/MTs. This paper aims to explain the importance of applying multicultural education in West Kalimantan by analyzing the content of the book, and implementation of such local content in some SMP/MTs. in Pontianak City. Data were obtained from local content of multicultural education for SMP/ $M T s$, relevant books, and print media. The results show that the history of the dark and traumatic cross-cultural festivities for the younger generation has encouraged some LSM to arrange local content material on multicultural education. This local content has been implemented in seven junior secondary schools in Pontianak. The themes discussed in the local content relate to the history of multicultural education, the multiethnic history and cultural diversity found in West Kalimantan, as well as an overview of interethnic interactions in West Kalimantan. The content of the local content contains five important aspects, namely cognitive, affective, psychomotor, social, and spiritual enabling able to build brotherhood and harmony of life.
\end{abstract}

Keywords: interethnic conflict, education, and multiculturalism.

\begin{abstract}
ABSTRAK
Tulisan ini mendeskripsikan bagaimana gagasan tentang multikulturalisme diintegrasikan ke dalam muatan lokal yang dijadikan sebagai materi pembelajaran di SMP/ MTs. Tulisan ini bertujuan menjelaskan pentingnya penerapan pendidikan multikultur di Kalimantan Barat dengan cara menganalisis isi buku, dan implementasi muatan lokal tersebut pada beberapa SMP/MTs. di Kota Pontianak. Data diperoleh dari buku muatan lokal
\end{abstract}


pendidikan multikultur untuk SMP/MTs, buku-buku yang relevan, dan media cetak. Hasil penelitian menunjukkan bahwa sejarah perseteruan antarentnis yang kelam dan traumatis bagi generasi muda telah mendorong beberapa LSM untuk menyusun materi muatan lokal tentang pendidikan multikultur. Muatan lokal ini telah diimplementasikan pada tujuh SMP/ MTs di Kota Pontianak.Tema-tema yang dibahas di dalam muatan lokal tersebut berhubungan dengan sejarah pendidikan multikultur, sejarah multietnik, dan keragaman budaya yang terdapat di Kalimantan Barat, serta gambaran mengenai interaksi antaretnis di Kalimantan Barat. Materi muatan lokal tersebut mengandung lima aspek penting, yaitu kognitif, afektif, psikomotorik, sosial, dan spiritual memungkinkan mampu membangun persaudaraan dan keharmonisan hidup.

Kata kunci: konflik, antaretnis, pendidikan, dan multikulturalisme.

\section{A. PENDAHULUAN}

Berbicara tentang ketegangan antaretnis di Kalimantan Barat (Kalbar) tidak terlepas dari rekaman peristiwaperistiwa yang telah terjadi sebelumnya. Giring (2003: 1-7) mendeskripsikan tentang bagaimana kronologi konflik etnik/SARA di Kalimantan Barat yang terjadi antara tahun 1997-2002. Misalnya, pada Januari 1997 di Sanggau Ledo (Kabupaten Sambas) pernah terjadi perkelahian antarpemuda di acara hiburan rakyat yang digelar di malam hari. Ketegangan antaretnis juga pernah berlangsung di Singkawang, Sambas, dan Wajok-Pontianak. Selanjutnya pernah pula terjadi konflik bernuansa etnik antara Melayu dengan Madura, yakni di tahun 1998 dan 1999. Peristiwa konflik yang terjadi tahun 2000 di Kota Pontianak juga melibatkan etnis Melayu dan Madura.

Konflik dan ketegangan yang pada mulanya berawal dari persoalan individu dan hanya melibatkan segelintir orang, tidak jarang bekembang menjadi semakin kompleks dan problematik. Selama ini, upaya penyelesaian konflik selalu dilakukan oleh pemerintah dan aparat keamanan dengan cara membuat perjanjian damai di antara kelompok etnik yang bertikai. Dalam perjanjian damai tersebut, kelompok etnik yang bertikai berkomitmen untuk tidak lagi saling mengganggu satu sama lain.

Apakah fenomena tentang konflik sosial tersebut bisa memengaruhi relasi antarpelajar di lingkungan sekolahnya masing-masing? Atau, jangan-jangan pengalaman konflik sosial yang pernah terjadi di masyarakat terekam juga oleh generasi muda yang kini menuntut ilmu di sekolah-sekolah menengah di Kota Pontianak? Dua pertanyaan ini mendorong penulis untuk menyelisik dan menelusuri lebih lanjut dampak negatif dari konflik sosial tersebut khususnya bagi generasi muda.

Ada sebuah pengalaman yang cukup mengusik penulis di bulan Oktober 2010, saat pertama kali penulis melihat tawuran pelajar yang terjadi secara brutal di salah satu sekolah menengah di Kota Pontianak. Kisah ini berawal dari ungkapan salah satu siswa 
yang menghina siswa lain yang berlatar belakang etnik tertentu. Kalimat yang diungkapkan demikian: "Otak kalian kecil kog, bisa simpan di loker saja!" Saat penulis menyaksikan perseteruan tersebut penulis menganggap bahwa peristiwa ini merupakan wujud dari perilaku kekerasan yang sering kali terjadi di kalangan generasi muda. Namun ternyata kalimat ejekan tersebut pada akhirnya mampu memicu konflik yang lebih besar di antara mereka. Pada hari berikutnya, terjadi tawuran yang berlangsung di luar lingkungan sekolah dan melibatkan sekelompok remaja dari etnik tertentu yang ada di Kota Pontianak. Ketika penulis bersama dewan guru mencari penyelesaian dari masalah tersebut, ada sebuah pernyataan yang diungkapkan oleh beberapa siswa. Bahwasanya sudah sejak lama mereka tidak suka dengan temannya yang selalu menganggap remeh kemampuan intelektual etnik tertentu.

Peristiwa ini memunculkan pertanyaan, mengapa para pelajar membicarakan persoalan etnik di lingkungan sekolah? Apakah narasinarasi tentang pengalaman sejarah konflik sosial yang terjadi di Kota Pontianak telah menimbulkan dendam di antara mereka? Peristiwa konflik sosial yang pernah terjadi di Kalbar dan pengalaman menangani perseteruan pelajar melatarbelakangi penulisan artikel ini. Penulis tertarik untuk memaparkan pentingnya pendidikan multikultural untuk diajarkan kepada siswa di lingkungan pendidikan di Kota
Pontianak.

Tirtosudarmono dalam Sudagung (2001: xviii-xix) mendeskripsikan bahwa jika dibandingkan dengan provinsi-provinsi lain, Kalimantan Barat dihuni oleh penduduk yang sangat heterogen dari sudut komposisi etniknya. Heterogenitas etnik di Kalbar disebabkan terutama oleh proses imigrasi masuk dari berbagai negara yang berbeda.

Menurut penulis, Kota Pontianak memiliki daya tarik tersendiri jika dilihat dari latar belakang sosial dan budaya masyarakatnya. Data Sensus Penduduk dari BPS tahun 2003 menunjukan adanya perubahan yang signifikan dalam komposisi penduduk menurut etnik di Kota Pontianak. Jumlah penduduk beretnik Dayak dan Melayu berimbang, yaitu: Melayu 33,75\%, Dayak 33,75\%. Sedangkan etnik Tionghoa 10,01\%, Jawa 9,41\%, Madura 5,5\%, Bugis 3,2\% dan etnik lainnya 1,85\% (Petebang, 2008: 18).

Kondisi sosial dan budaya masyarakat Kota Pontianak yang plural tersebut berpotensi untuk memunculkan konflik laten dan manifes. Konflik laten yang dimaksud di sini adalah potensi-pontensi konflik terpendam yang melatarbelakangi terjadinya konflik manifes. Konflik manifes bisa terjadi karena adanya perbedaan-perbedaan sosial dan budaya di antara warga masyarakat ataupun siswa, misalnya perbedaan latar belakang agama, suku, maupun ras. Selama ini konflik-konflik tersebut seolah-olah seperti dirawat, sekali 
waktu bisa muncul seketika menjadi konflik yang terbuka di masyarakat.

Berbagai kasus kekerasan yang terjadi di lingkungan sekolah, tawuran antarpelajar, serta konflik antaretnis dapat menimbulkan trauma tersendiri bagi para pelajar, khususnya bagi mereka yang mengalaminya secara langsung dan turut menjadi korban. Kondisi ini berpontensi untuk mengganggu perkembangan jiwa mereka. Fenomena tentang kasus-kasus konflik dan kekerasan yang terjadi di dunia pendidikan telah menjadi perhatian penulis selama menjalankan tugas sebagai pengajar di Kota Singkawang dan Pontianak, sehingga pada akhirnya mendorong penulis untuk melakukan kajian yang lebih mendalam.

Munculnya kesadaran akan potensi negatif dari konflik sosial bagi perkembangan generasi muda di Kota Pontianak telah mendorong pemerhati pendidikan khususnya kalangan aktivis dari Lembaga Swadaya Masyarakat (LSM) menginisiasi sebuah model baru dalam aktivitas pembelajaran di SMP dengan menerapkan muatan lokal pendidikan multikultur. Sekolahsekolah yang dipilih untuk penerapan muatan lokal ini adalah beberapa SMP di Kota Pontianak yang mayoritas peserta didiknya berasal dari etnik tertentu.

Tulisan ini berfokus pada tiga permasalahan berikut ini, yaitu: (1) mengapa pendidikan multukultur penting untuk diterapkan di Kalimantan Barat?; (2) bagaimana gambaran tentang materi muatan lokal tentang pendidikan multikultur untuk SMP?; (3) bagaimana muatan lokal tentang pendidikan multikultur tersebut. diimplementasikan dalam aktivitas pembelajaran?

Adapun tujuan dari penelitian ini adalah untuk menjelaskan pentingnya penerapan pendidikan multikultur di Kalimantan Barat, menganalisis isi buku muatan lokal pendidikan multikultur untuk SMP, serta mengetahui implementasi muatan lokal pendidikan multikultur tersebut di beberapa SMP di Kota Pontianak.

Penelitian ini merupakan studi kepustakaan, yaitu buku muatan lokal pendidikan multikultur untuk SMP/ MTs yang membahas tentang multikulturalisme dan pendidikan multikultur, serta media cetak merupakan sumber utama bagi penulis untuk memperoleh data yang disajikan dan dianalisis di dalam tulisan ini.

Konsep multikulturalisme yang belakangan menjadi sebuah perbincangan hangat di tengah kondisi bangsa yang plural ini sebenarnya sudah digagas sejak lama. Konsep ini tertuang dalam pasal 32 UUD 1945, yang berbunyi "Kebudayaan bangsa (Indonesia) adalah puncak-puncak kebudayaan di daerah." Kebudayaan sendiri merupakan bentuk majemuk dari kata budi-daya yang memiliki arti cipta, karsa, dan rasa. Kebudayaan juga dapat dimaknai sebagai culture, yaitu sebagai segala daya dan aktivitas manusia untuk mengolah dan mengubah alam. Dari penjelasan 
pengertian di atas dapat ditarik hubungan antara keduanya, yakni kebudayaan lahir dari proses belajar yang merupakan kegiatan dari dunia pendidikan. Penerapan nilai-nilai budaya bangsa yang bersumber dari beragam budaya lokal/daerah ini menjadi efektif jika disampaikan melalui suatu proses pembelajaran, yang dibingkai oleh pendidikan multikultur.

Multikulturalisme ditinjau dari sudut pandang etimologisnya berasal dari kata multi (plural) dan kultural (berkaitan erat dengan budaya). Maka multikulturalisme merupakan pengakuan terhadap realitas keragaman kultural yang mencakup keragaman tradisional, antara lain: ras, suku, agama, maupun keberagaman bentukbentuk kehidupan (subcultural) yang secara kontinu muncul pada setiap tahap kehidupan manusia. Jadi dengan kata lain multikulturalisme menekankan keanekaragaman kebudayaan dalam kesetaraan derajat dan toleransi.

Pendidikan multikultural merupakan fenomena yang relatif baru di dalam dunia pendidikan. Sebelum Perang Dunia II boleh dikatakan pendidikan multikultural belum dikenal. Orientasi pendidikan pada zaman itu dijadikan sebagai alat politik untuk melanggengkan kekuasaan yang memonopoli sistem pendidikan untuk kelompok tertentu. Pendidikan multikultural merupakan gejala baru di dalam pergaulan umat manusia yang mendambakan hak untuk mendapatkan pendidikan yang sama untuk semua orang: "Education for All".

Bhiku Parekh (2008: 13-24) $\mathrm{dalam} \mathrm{buku} \mathrm{Rethinking}$ Multiculturalism mengatakan bahwa pada abad ke-19 keberagaman budaya dan teori politik berawal dari situasi di negara Inggris dan Eropa. Di sini Parekh berbicara panjang lebar tentang multikulturalisme mulai sejarah asal mulanya sampai pada kesalahpahaman tentang multikulturalisme. Parekh melihat bahwa kelompok minoritas dan imigran mengalami diskriminasi dan ketidakadilan dalam segala aspek kehidupan. Kebijakan para pemimpin negara hanya menguntungkan bagi warga mayoritas dan pola keseragaman yang diterapkan dalam kebijakankebijakan tersebut telah membuat kelompok-kelompok lain tidak berdaya.

Senada dengan itu, Tilaar (2004: 127-166) ${ }^{1}$ juga mendeskripsikan lahirnya pendidikan multikultur di beberapa negara yakni: Pertama, di Amerika berawal dari ratapan seorang siswa sekolah menengah atas di Boston pada abad ke-20. Negara ini sangat mengagungkan dirinya sebagai penjaga demokrasi. Ternyata di dalam masyarakatnya sendiri pelaksanaan prinsip-prinsip demokrasi masih

\footnotetext{
1 Tilaar mendeskripsikan bahwa sejarah dan latar belakang pendidikan multikulturalisme di suatu negara tumbuh dan berkembang sesuai dengan budaya yang ada di negara tersebut. Semuanya tidak lepas dari gejala hidup masyarakat yang mengalami perubahan cara berpikir yang terjadi setiap hari, misalnya tentang konsep mayoritas, minoritas, multietnik, sampai kepada eksistensial diri.
} 
memerlukan jalan yang panjang. Kedua, pendidikan multikultur di Jerman tidak terlepas dari kekalahan Jerman di Perang Dunia I, yang ditandai dengan runtuhnya runtuhnya kekaisaran Austria-Hongaria dan Jerman sendiri. Perjanjian Versailles menyebabkan berdirinya negara-negara yang multietnik dan heterogen, seperti Cekoslovakia dan Yugoslavia, serta perubahan batas-batas wilayah suatu negara. Ketiga, sejarah pendidikan multikultural di Inggris tidak terlepas dari sejarah perkembangan atau revolusi industri yang terjadi di Inggris abad ke-18. Pada saat itu, diskriminasi yang dilakukan oleh ras kulit putih sangat kuat terhadap ras kulit hitam. Keempat, pendidikan multikultur di Kanada mengambil bentuknya yang khusus. Komposisi penduduk berdasarkan etnik yang tidak seimbang membuat masyarakat mengidentifkasi diri mereka sesuai dengan salah satu kelompok dari empat kelompok besar yang dikenal di masyarakat, yakni : Ontario, Nova Scotia, Quebec dan Britis Columbia.

Kelima, pendidikan multikultur di Australia yang tidak terlepas dari sejarah penduduk asli di sana, yaitu suku Aborigin, yang berasal dari benua Asia 50 ribu tahun lalu. Penduduk asli ini mengalami ketidakadilan dan berada di bawah tekanan politik yang dilakukan oleh ras kulit putih. Keenam, pendidikan multikultur di Afrika Selatan memiliki keterkaitan dengan praktik politik segregasi atau politik apartheid yang diterapkan dengan sangat keras hingga tahun 1994. Terjadinya reformasi struktur pendidikan di tahun 1980 ditandai dengan didirikannya The Lange Commission oleh pemerintah. Komisi yang meneliti kembali efektivitas struktur pendidikan berdasarkan ras ini, di tahun 1981 merekomendasikan hal-hal sebagai berikut: 1) diperlukan satu sistem pendidikan untuk semua ras; 2) kewajiban belajar enam tahun untuk semua anak; dan 3) menyelenggarakan pendidikan dasar (basic education) untuk semua.

Bagaimana dengan sejarah pendidikan multikultur di Indonesia? Wacana tentang multikulturalisme dalam masyarakat Indonesia dapat dikatakan sudah ada sejak proses perjuangan untuk membentuk negara ini (Darmawan, 2005: 182-185). Lahirnya "Soempah Pemoeda yang digagas oleh sekian banyak kelompok pemuda dari berbagai etnik (Jong Java, Jong Ambon, Jong Celebes) di tahun 1928, dapat dilihat sebagai hasil dari wacana itu.

Perdebatan tentang wacana multikulturalisme berlangsung pula dalam persoalan kedudukan etnik Tionghoa di Indonesia (Tanuhandaru, 2008: 36-60). Namun selama rezim Orde Baru berkuasa, atas dalih untuk mencegah terjadinya konflik berbasis SARA, masalah-masalah yang berkaitan dengan hubungan antarkelompok SARA menjadi tabu untuk dipersoalkan. Konsekuensinya, wacana multikulturalisme menjadi tidak berkembang. Multikulturalisme 
yang ada berwajah tunggal di bawah kebijakan integrasi dan asimilasi yang sentralistik. Dalam konteks etnik minoritas Tionghoa, multikulturalisme bahkan tidak berlaku. Hal itu sebagai akibat dari kebijakan resmi yang diterapkan oleh pemerintah kala itu yang bertujuan untuk meleburkan kelompok minoritas ini ke dalam kelompok mayoritas. Pada akhirnya tidak ada lagi identitas sosio-kultural Tionghoa dalam himpunan masyarakat Indonesia pada zaman orde baru (Siegel, 2000: 188-189). ${ }^{2}$

Berdasarkan penjelasan yang telah dipaparkan sebelumnya, penulis kemudian menganalisis pendidikan multikultur seperti apa yang membedakan wajah multikulturalisme di Indonesia dengan di negara-negara Barat? Secara konseptual tampaknya lebih cocok dikatakan bahwa situasi yang dikembangkan di Indonesia adalah wacana pluralisme. Ini terutama menjadi jelas dalam konstelasi hubungan antara kelompok agama mayoritas dengan minoritas.

Istilah "etnis", "etnisitas", dan "etnisisme" merupakan sesuatu yang relatif baru dalam bahasa Indonesia. Tadinya, yang dipergunakan adalah

\footnotetext{
2 Tulisan Siegel menguraikan tentang konflik laten dan manifes di Indonesia, khususnya kerusuhan yang terjadi di Kota Jakarta. Nuansa rasial dalam peristiwa ini tampak melalui kasus-kasus yang menjadikan etnik Tionghoa sebagai sasaran dan target dari para perusuh. Bagi penulis, peristiwa 13-14 Mei 1998 menjadi bahan refleksi mengenai stereotip orang pribumi terhadap etnik Tionghoa.
}

istilah "suku", "sukuisme", dan "kesukuan". Singgih dalam Abdilah (2002: ix) ${ }^{3}$ melukiskan tentang keberadaan Indonesia sebagai negara kesatuan yang didiami oleh berbagai suku, tetapi kebangsaannya hanya satu, yakni bangsa Indonesia. Dari gagasan ini seolah-olah sebutan "etnis" dianggap datang dari luar meskipun dalam kenyataan sudah berabad-abad tinggal di Indonesia, misalnya etnis Cina dan Arab, pada hal bisa juga menyebut etnis Jawa, Batak, Flores, Bugis dan lain sebagainya. Sebutan etnis begitu sensitif bagi identifikasi seseorang. Seakan-akan selalu kembali ke sejarah kelam asal mula orangorang tersebut datang ke Indonesia.

\section{B. HASIL DAN BAHASAN}

\section{Ulasan Tentang Pendidikan Multikultur}

Pendidikan multikultur terdiri dari dua bagian penting, yaitu: pendidikan dan multikulturalisme. Pengertian pendidikan telah banyak ditemukan oleh berapa ahli/pakar pendidikan. Salah satunya adalah pandangan Sastraprajatedja (2013: 24-29) tentang teori pendidikan model Paulo Freire yang melihat permasalahan pendidikan sebagai masalah struktural yang berkaitan dengan masalah sosioekonomis, politik dan kebudayaan.

\footnotetext{
${ }^{3}$ Singgih dalam buku Politik Identitas Etnis, menjelaskan panjang lebar soal pemahaman etnisitas dan etnisisme. Menurutnya, kedua istilah ini merupakan sesuatu yang relatif baru dalam percakapan bahasa Indonesia seharihari.
} 
Paulo yang mengecam sistem pendidikan gaya bank (banking system) berpendapat bahwa sistem pendidikan dapat memperkuat struktur yang kurang adil dalam masyarakat. Dia ingin mendobrak sistem pendidikan lama dengan sistem pendidikan yang membebaskan, yaitu guru dan murid belajar bersama (saling belajar). Guru dan murid bersama-sama mengembangkan kemampuanya untuk secara kritis memahami dirinya sendiri dan dunianya. Dalam proses belajar ada dialog. Inti dari dialog adalah kata yang merupakan refleksi dan aksi. Tanpa refleksi akan terjadi aktivisme dan tanpa aksi terjadi verbalisme. Dialog menuntut kepekaan akan bakat-bakat bawaan di dalam diri tiap manusia dan dialog berarti memperlakukan orang lain sederajat.

Driyarkara sebagai tokoh filsafat pendidikan Indonesia (dalam Sudiarja, 2014: 29) mendeskripsikan bahwa pendidikan sebagai proses memanusiakan manusia muda. Tulisantulisan Driyarkarya menunjukkan bahwa dia mempertahankan pandangan tradisional, khususnya tentang pendidikan humaniora. Sejalan dengan pandangan Thomas Aquinas, Driyarkara berpendapat bahwa pendidikan adalah proses humanisasi dan hominisasi, artinya pemanusiaan menyangkut keseluruhan jiwa dan badan. Tradisi humaniora tersebut telah mendasari perkembangan UU Pendidikan, seperti tampak pada rumusan tujuan pendidikan, yakni: "mengembangkan manusia Indonesia seutuhnya, yaitu manusia beriman dan bertaqwa terhadap Tuhan yang Maha Esa dan berbudi pekerti luhur, memiliki pengetahuan dan keterampilan, kesehatan jasmani dan rohani, kepribadian yang mantap dan mandiri, serta rasa tanggung jawab kemasyarakatan dan kebangsaan".

Bagaimana dengan penjelasan tentang multikulturalisme? Multikulturalisme adalah istilah yang digunakan untuk menjelaskan pandangan seseorang tentang ragam kehidupan di dunia, ataupun kebijakan kebudayaan yang menekankan penerimaan terhadap adanya keragaman dan berbagai macam budaya (multikultural) yang ada dalam kehidupan masyarakat.

Kamus Besar Bahasa Indonesia (KBBI) mengartikan multikulturalisme sebagai semacam gejala pada seseorang atau suatu masyarakat yang ditandai oleh kebiasaan menggunakan lebih dari satu kebudayaan (https://www.kbbi. web.id, diakses 27 Maret 2018). Maka multikulturalisme adalah pengakuan terhadap realitas keragaman kultural mencakup baik keberagaman tradisional seperti keberagaman suku, ras, ataupun agama, maupun keberagaman bentuk-bentuk kehidupan (subkultur) yang terus bermunculan di setiap tahap sejarah kehidupan masyarakat. Sedangkan kata pluralisme lebih berhubungan dengan hak hidup kelompok-kelompok masyarakat yang ada dalam sebuah komunitas yang mempunyai budaya masing-masing.

Kristiyanto (2014: 1) mempunyai 
perspektif historis tersendiri mengenai multikulturalime ini. Dikatakannya bahwa istilah multikulturalisme belum menjadi kosa kata yang lazim digunakan. Wacana multikulturalisme menguat seiring dengan munculnya praktik demokrasi sebagai pilihan politik yang dijalankan demi kesejahteraan yang merata dan berkeadilan. Selain itu wacana tentang multikulturalisme juga dipersubur oleh kebutuhan untuk merumuskan identitas diri sebagai bangsa (nation) yang otonom, yang tidak didikte oleh kepentingan politik, ekonomi, dan budaya bangsa lain atau kelompok tertentu.

Multikulturalisme menekankan keanekaragaman kebudayaan dalam kesederajatan. Multikulturalisme lahir dari benih-benih konsep yang sama dengan demokrasi, supremasi hukum, hak asasi manusia, prinsip-prinsip etika dan moral egaliter sosial-politik. Lahirnya paham multikulturalisme berlatar belakang kebutuhan akan pengakuan (the need of recognition) terhadap kemajemukan budaya yang menjadi realitas sehari-hari banyak bangsa, termasuk Indonesia. Oleh karena itu, sejak semula multikulturalisme harus disadari sebagai suatu ideologi yang menjadi alat atau wahana untuk meningkatkan penghargaan atas kesetaraan semua manusia dan kemanusiaannya yang secara operasional mewujud melalui pranatapranata sosial, yakni budaya sebagai pemandu kehidupan sekelompok manusia sehari-hari. Dalam hal ini, multikulturalisme adalah konsep yang melegitimasi keanekaragaman budaya.

Suryana dan Rusdiana (2015: 199) mendeskripsikan tujuan pendidikan multikultur yaitu mengubah pendekatan dan pembelajaran ke arah yang memberi peluang yang sama pada setiap siswa. Tidak ada yang dikorbankan demi persatuan. Untuk itu kelompokkelompok harus damai, saling memahami, mengakhiri perbedaan, tetapi tetap menekankan pada tujuan umum untuk mencapai persatuan. Pada siswa ditanamkan pemikiran lateral, keanekaragaman, dan keunikan untuk dihargai dengan literasi budaya. Hal ini berarti harus ada perubahan sikap, perilaku, dan nilai-nilai khususnya civitas akademika sekolah. Ketika siswa berada di antara sesamanya yang berlatang belakang berbeda, mereka harus belajar satu sama lain, berinteraksi, dan berkomunikasi sehingga dapat menerima perbedaan di antara mereka sebagai sesuatu yang memperkaya mereka. Dalam pendidikan multikultur, perbedaan yang ada pada setiap siswa harus diakui, antara lain yang berkaitan dengan etnik dan ras, kelompok pemeluk agama, jenis kelamin, kondisi ekonomi, daerah/ asal-usul, ketidakmampuan fisik dan mental, kelompok umur, dan lain-lain (Baker, 1994:11).

Tilaar (2004: 185-190) menguraikan bahwa nilai-nilai dalam pendidikan multikultur yang dapat mentransformasikan pendidikan nasional, terutama dalam beberapa dimensi sebagai berikut. (1) Right to 
culture dan identitas budaya lokal: multikulturalisme didorong oleh pengakuan terhadap hal asasi manusia;

(2) Kebudayaan Indonesia yang menjadi: maksudnya suatu pegangan dari setiap insan dan setiap identitas budaya mikro Indonesia; (3) Pendidikan multikultur yang normatif: konsep yang dapat digunakan untuk mewujudkan cita-cita; (4) Kultural rekontruksi sosial: untuk melihat kembali kehidupan sosial yang ada saat ini; (5) Pendidikan multikultur di Indonesia memerlukan pedagogik baru; dan (6) Pendidikan multikultur bertujuan untuk mewujudkan visi Indonesia di masa depan serta etika berbangsa.

Muhamad Ali (2003: 103) mengatakan bahwa pendidikan multikultur berkaitan dengan istilah pluralis-multikulturalis, yang tidak sekedar untuk memahami keragaman agama dan budaya saja, tetapi juga untuk memahami nilai-nilai bersama yang bisa dibagikan antara satu dengan yang lain, sebagai dasar hidup bersama (vivre ensemble). Ali pun menemukan tujuan pendidikan pluralismultikultural sebagai upaya untuk menanamkan simpati, apresiasi, dan empati terhadap penganut agama dan budaya yang berbeda. Lebih jauh lagi, penganut agama dan budaya yang berbeda dapat belajar untuk melawan ketidaktoleranan (intorelable) seperti inkuisisi (pengadilan Negara atas sahtidaknya teologi atau ideologi), perang agama, dan diskriminasi.

Gagasan di atas didukung pula oleh Suparno (2015: 143-154) yang menggambarkan semangat multikulturalisme dalam perwujudan yang praktis, yakni para peserta didik merasakan langsung bagaimana hidup bersama dengan orang lain. Adapun tujuannya adalah agar siswa dapat menerima, bekerja sama dan bergaul dengan teman-teman yang berbeda budaya, golongan, suku, agama dan gender, serta menghargai setiap orang dalam perbedaan. Menurut Suparno siswa sendiri menyadari bahwa Indonesia terdiri dari beragam budaya, agama, suku dan pulau. Bangsa ini akan kuat bila yang berbeda-beda itu saling menerima dan menghargai, serta mau bekerja sama dengan mereka. Maka budaya multikultural perlu diadakan sejak di sekolah. Budaya multikultural ini perlu terus dilatih di sekolah agar siswa dapat dengan mudah menerima teman yang berbeda agama, suku, lingkungan dan sebagainya. Mereka juga dengan gembira mau bekerja sama dalam kelompok dan melakukan proyek bersama. Latihan seperti ini akan membantu perkembangan karakter mereka dan nantinya membantu dalam pembentukan bangsa yang kuat.

Hopkins-Gillidpie (2011: 1-7) dalam Jurnal Curriculum \& Schooling: Multiculturalism, Critical Multiculturalism and Critical Pedagogy menyampaikan tentang konsep pendidikan multikultur. Adapun fungsi dari pendidikan multikultur adalah sebagai kendaraan untuk masyarakat umum dan menjadi salah satu bentuk reformasi pendidikan di dalam masyarakat. Pendidikan multikultur 
diharapkan dapat membantu siswa untuk memperoleh wawasan, pengetahuan, keterampilan dan komitmen yang diperlukan, sehingga bangsa dan dunia lebih responsif terhadap kondisi manusia yang ada di masyarakat.

\section{Konteks Pendidikan Multikultur di Kalimantan Barat}

Telah diketahui bersama bahwa konflik antaretnis di Kalbar merupakan bentuk nyata dari kekerasan dan tragedi kemanusian yang perlu mendapat perhatian serius dari masyarakat dan pemerintah. Konflik dan kekerasan tersebut sudah menjadi semacam benang kusut yang telah berlangsung puluhan tahun. Peristiwa pertikaian antaretnis Madura dan Dayak di Kalbar pada penghujung 1996 dan awal tahun 1997 telah menimbulkan trauma dan luka batin. Tentu saja terdapat peserta didik yang ikut merekam peristiwa tersebut, bahkan ada di antaranya yang menjadi korban. Pengalaman pahit tentang konflik sosial ini dapat memengaruhi persepsi dan menguatkan stereotip mereka terhadap kelompok etnik yang berbeda. Selain itu, konflik sosial pun bisa memberikan dampak negatif bagi perkembangann jiwa dan menggangu interaksi sosial di kalangan generasi muda, baik di lingkungan sekolah maupun keluarga, misalnya dengan tumbuhnya rasa curiga dan prasangka terhadap orang lain yang berbeda dengannya.

Dari beberapa kajian mengenai konflik sosial di Kalbar digambarkan bahwa hubungan antaretnis di Kalbar selama ini cenderung diwarnai oleh prasangka etnis. Hasil penelitian juga memperlihatkan adanya dominasi etnik tertentu dalam bidang ekonomi atau di lapangan pekerjaan tertentu, hubungan antaretnis yang didasari oleh persaingan, serta dendam yang terakumulasi dari peristiwa-peristiwa konflik yang terjadi sebelumnya, terlebih yang berakibat pada hilang/ musnahnya harta benda dan munculnya korban jiwa. Pada masyarakat yang bercorak multietnik, dominasi kelompok tertentu di bidang kebudayaan akan memperkuat relasi kuasa dan politik identitas. Konflik horisontal pun akan semakin menguat seiring dengan semakin menguatnya relasi kuasa dan politik identitas tersebut.

Penulis menemukan bahwa disharmoni sosial menjadi akar penyebab dari konflik antaretnis. Meletusnya kasus-kasus konflik antaretnis di beberapa daerah di Kalbar, khususnya di Kota Pontianak, merupakan bukti masih adanya kerenggangan dalam tali persaudaraan antara beragam etnik yang hidup berdampingan di Kalbar. Tindak kekerasan seakan-akan menjadi salah satu cara yang dipilih untuk mengungkapkan ketidaksukaan terhadap kelompok lain. Integrasi sosial yang seharusnya terjadi antara masyarakat pendatang dengan penduduk lokal masih bersifat artifisial dan belum menyentuh nilai-nilai kemanusian yang sesungguhnya. 
Mungkinkah kerenggangan dan kepincangan sosial yang terjadi di dalam masyarakat merupakan buah dari struktur pemerintahan Orde Baru dengan sentralistik? Selama kekuasaan orde baru pengalaman-pengalaman ketidakdilan yang dirasakan oleh warga lokal ditambah dengan karakter, sikap, dan perilaku oknum warga pendatang yang agak kurang bersahabat dengan orang lain di luar komunitasnya, dalam batas tertentu mengganggu keharmonisan dalam pergaulan hidup bersama. Reaksi yang muncul karena kondisi tersebut bisa berupa kejengkelan dan kebencian. Ketidakpuasan yang telah lama terakumulasi itu diungkapkan dalam bentuk tindak kekerasan yang merugikan semua pihak. Kasus antarpribadi dengan sekejap berkembang menjadi konflik dan pertikaian sosial.

Penyebab lainnya adalah melemahnya otonomi personal sehingga warga dengan mudah dimobilisasi untuk melakukan kekerasan. Kondisi ini merupakan bagian dari keunikan masyarakat tradisional yang tingkat pendidikannya relatif masih rendah. Kelompok masyarakat ini agaknya yang mudah emosi, cepat terhasut, dan kurang mampu memilah-milah mana yang merupakan persoalan pribadi dan mana yang kelompok. Mereka bahkan tak sanggup berpikir secara jernih tentang dampak dari tindakan kekerasan yang sedang dan akan dilakukan tersebut.

Beberapa aktivis LSM di Kalbar mengaitkan antara kekerasan yang kerap terjadi di berbagai belahan bumi, termasuk di Kalbar, dengan ketidakadilan, perilaku penindasaan yang dilakukan oleh kaum kaya terhadap kaum miskin, serta kebijakan pemerintah yang tidak tepat. Mereka beranggapan konflik-konflik sosial yang disertai dengan perilaku kekerasan dipicu oleh adanya budaya kekerasan yang tumbuh di masyarakat (Herlambang, 2013: vi) ${ }^{4}$. Oleh karena pemicunya adalah budaya, maka harus pula dilawan dengan budaya, yakni budaya anti kekerasan (non violence). Ada banyak wadah untuk menanamkan budaya damai, antara lain melalui media massa, cultural study, dan lembaga pendidikan perdamaian.

Wilayah Kalbar merupakan salah satu daerah yang di masa lalu pernah mengalami konflik kekerasan yang bernuansa etnik. Konflik kekerasan di Kalbar harus menjadi pelajaran yang sangat penting bagi seluruh warganya, bahwa dalam setiap konflik ternyata hanya menghasilkan kehancuran bagi seluruh sendi kehidupan manusia.

Sejarah kelam konflik sosial dan kekerasan yang terjadi di Kalbar menjadi sebuah narasi yang diceritakan secara turun temurun, dari satu generasi ke generasi berikutnya. Oleh karena itu, pendidikan multikultur perlu diimplementasikan di kalangan

\footnotetext{
${ }^{4}$ Herlambang menggambarkan dalam tulisanya bahwa bagaimana pemerintahan Orde Baru dan agen-agen kebudayaanya memanfaatkan produk-produk budaya dalam melegitimasi kekerasan terhadap kaum komunis melalui sastra dan film.
} 
generasi muda, salah satunya melalui proses belajar di sekolah. Pendidikan multikultur merupakan langkah awal dalam perencanaan mencari jalan keluar dari upaya menghentikan konflik sosial.

Di Kalimantan Barat, gagasan tentang multikulturalisme ini diperkenalkan melalui penyusunan materi pembelajaran untuk pendidikan multikultur di tingkat SMP melalui muatan lokal. Selain harus diterapkan secara berkelanjutan, perlu pula dicari model-model lain yang bertujuan untuk pembangunan perdamaian di Kalbar. Upaya-upaya tersebut harus melibatkan semua pihak, baik individu maupun pemerintah sebagai pihak yang bertanggung jawab untuk memenuhi, melindungi dan menghormati hak-hak rakyatnya.

Dalam konteks itu ANPRI ${ }^{5}$ menginiasi sejumlah aktivitas yang bertujuan untuk membangun perdamaian di Kalbar. Salah satunya adalah dengan melakukan fasilitasi dalam pengajaran muatan lokal pendidikan multikultur. Dalam pelaksanaannya, ANPRI bekerja sama dengan tujuh SMP/MTs swasta, yang latar belakang siswanya berasal dari empat kelompok

\footnotetext{
${ }^{5}$ ANPRI adalah aliansi strategis dari enam organisasi non pemerintah multietnik yang aktif melakukan upaya-upaya pembangunan perdamaian dan rekonsiliasi di Kalimantan Barat. Aliansi tersebut terdiri dari Institut Dayakologi (berbasis etnik Dayak), Lembaga Gemawan (berbasis etnik Melayu), Mitra Sekolah Masyarakat (berbasis etnis Madura), Badan Koordinasi Koperasi Kredit Daerah Kalbar, Sekretariat Segerak-Pancur Kasih dan PEK-Pancur Kasih.
}

etnik besar di Kalbar. Keempat kelompok etnik tersebut beberapa kali pernah terlibat dalam konflik sosial. Berikut adalah tabel yang menggambarkan tentang ketujuh sekolah tempat diterapkannya pendidikan multikultur di Kota Pontianak.

\begin{tabular}{|c|l|c|l|}
\hline No & \multicolumn{1}{|c|}{ SMP/MTs } & Basis Etnis & \multicolumn{1}{|c|}{ Lokasi } \\
\hline 1 & SMP St.Fransiskus Asissi & Tionghoa & $\begin{array}{l}\text { Kota } \\
\text { Pontianak }\end{array}$ \\
\hline 2 & SMP Haruniyah & $\begin{array}{c}\text { Melayu, } \\
\text { Bugis }\end{array}$ & $\begin{array}{l}\text { Kota } \\
\text { Pontianak }\end{array}$ \\
\hline 3 & MTs Nurul Alamiah & Madura & $\begin{array}{l}\text { Wajok, Kab. } \\
\text { Pontianak }\end{array}$ \\
\hline 4 & MT s Nahdatul Atfal & Madura & $\begin{array}{l}\text { Sui, } \\
\text { Ambawang, } \\
\text { Kubu Raya }\end{array}$ \\
\hline 5 & SMP Katolik & Dayak & $\begin{array}{l}\text { Pahauman, } \\
\text { Kab. Landak }\end{array}$ \\
\hline 6 & SMP Don Bosco & Dayak & $\begin{array}{l}\text { Menjalin, } \\
\text { Kab. Landak }\end{array}$ \\
\hline 7 & SMP Gerpemi & Melayu & $\begin{array}{l}\text { Tebas, Kab. } \\
\text { Sambas }\end{array}$ \\
\hline
\end{tabular}

Táuel 1. Sekơlân Peláksanáa Penủiủikan Multikultur di SMP Pontianak Kalbar. Sumber: Petebang et al, 2008:12.

Tujuan dari pendidikan multikultur ini adalah untuk mencegah secara dini terjadinya konflik antaretnis di masa yang akan datang. Dalam konteks pendidikan multikutur yang disampaikan di sekolah, pencegahan konflik sosial tersebut dapat dimulai dengan mencegah terjadinya ketegangan dalam interaksi sosial antara siswa dari etnik Dayak, Melayu, Madura, dan Tionghoa, baik di lingkungan sekolah maupun di masyarakat.

\section{Isi Buku Pendidikan Multikutur di Sekolah Menengah Kalbar}

Setelah dipelajari secara seksama buku mata pelajaran Muatan Lokal 
(Mulok) Pendidikan Multikultur Kalimantan Barat untuk SMP/MTs ini dari sisi kurikulum sudah sesuai dengan kurikulum yang berlaku, yakni KTSPStandar Isi. Dari sudut materi atau bahan ajarnya pun sudah memadai. Buku mulok pendidikan multikultur ini disusun dan diterapkan untuk kelas VII, VIII dan IX.

Pada bagian selanjutnya, penulis akan mengulas secara singkat bagianbagian penting yang terdapat di dalam buku tersebut.

\subsection{Buku Mulok Pendidikan Multikultur Kelas VII}

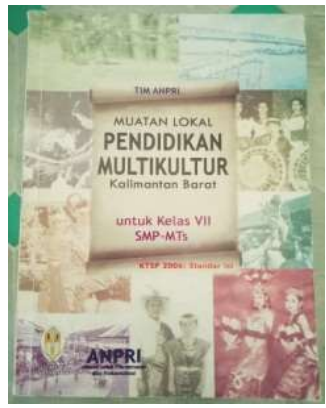

Gambar 1. Buku Pendidikan Multikultur Kalimantan Barat Untuk SMP/MTs Kelas VII

Sumber: Petebang et al., 2008.

Standar kompetensi capaian siswa dalam buku tersebut adalah siswa mampu memahami konsep dasar dan arti pentingnya pendidikan multikultur, mengenal dan memahami kondisi bahwa Kalbar sebagai wilayah yang multikultural, serta mampu menjadikan kondisi multikultural sebagai potensi untuk memajukan Kalbar.

Penjabaran kompetensi tersebut dibahas di dalam enam bab, yakni: (1) pendidikan multikultur; (2) mengenal multikultur di Kalimantan Barat; (3) interaksi masyarakat multietnik di Kalbar; (4) pesta panen masyarakat Dayak Kalimantan Barat; (5) budaya masyarakat Melayu Kalbar; dan (6) permainan Barong Saai dan Naga dari etnik Tionghoa.

Uraian singkat dari tiap bab itu adalah sebagai berikut. Bab pertama, peserta didik mempunyai pengetahuan tentang latar belakang lahirnya pendidikan multikultur dan pengertian pendidikan multikultur. Kemudian siswa mengetahui bagaimana konteks pendidikan multikultur di Kalbar untuk mewujudkan toleransi. Bab kedua mengenalkan histori multietnik di Kalbar, sehingga siswa mengenal gambaran singkat mengenai etnik Dayak, Melayu, Tionghoa, Madura dan etnis lainnya. Bab ketiga, siswa mengetahui dan mendalami pola-pola interaksi masyarakat multietnik di Kalbar. Misalnya, dibahas tentang interaksi masyarakat Madura dengan Dayak, Dayak dengan Melayu, Dayak dengan Tionghoa, Tionghoa dengan Madura, Madura dengan Melayu, Melayu dengan Tionghoa, seperti yang terdapat di halaman 51-64. Bab ini ditutup dengan interaksi antara Dayak, Melayu, Tionghoa, Madura dan etnis lainya. Di bab keempat lebih mempelajari pesta naik dango (Dayak), di bab lima mempelajari ritual antar anjung dan festival meriam karbit (Melayu), sedangkan di bab enam mendeksripsikan budaya Tionghoa melalui tarian naga dan barongsai. 


\subsection{Buku Mulok Pendidikan Multikultur Kelas VIII}

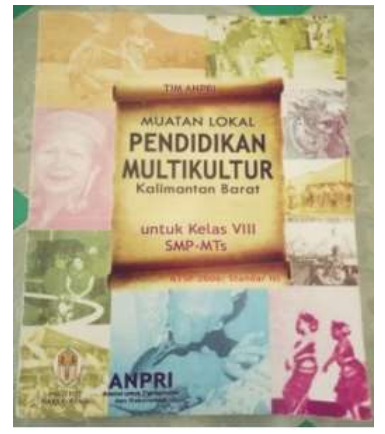

Gambar 2. Buku Pendidikan Multikultur Kalimantan Barat Untuk SMP/MTs Kelas VIII

Sumber: Petebang et al., 2011.

Dalam buku Mulok Pendidikan Multikultur Kalimantan Barat Untuk SMP/MTs Kelas VIII ditemukan pembahasan mengenai adat istiadat dari beragam kebudayaan di Kalbar. Di sini standar kompetensi yang harus dicapai oleh siswa adalah mampu menghargai, menerima dan menghormati beranekaragam perbedaan dalam masyarakat, sehingga tercipta masyarakat multietnik Kalbar yang damai.

Deskripsi materi pembelajarannya adalah sebagai berikut: bab pertama tentang adat kelahiran yang berlaku di berbagai etnik di Kalbar; bab kedua membicarakan adat perkawinan yang berlaku di berbagai etnik di Kalbar; sementara pada bab selanjutnya memfokuskan diri pada pembahasan mengenai kesenian Dayak, Melayu, Tionghoa, Madura serta etnik-etnik lainnya (Jawa, Bugis, Batak, Bali dan NTT) di Kalbar.

\subsection{Buku Pendidikan Multikultur} untuk Kelas IX

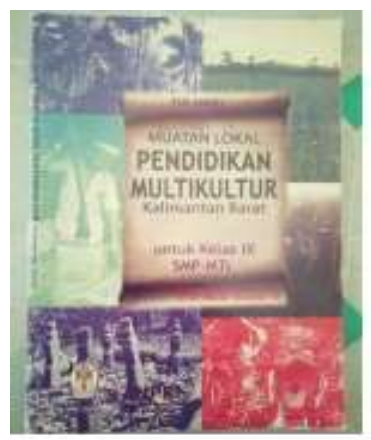

Gambar 3. Buku Pendidikan Multikultur Kalimantan Barat Untuk SMP/MTs Kelas IX

Sumber: Petebang et al., 2011.

Standar kompetisi yang terdapat pada buku mulok di kelas IX sama dengan standar kompetensi di kelas VIII, yakni siswa menghargai, menerima dan menghormati beranekaragam perbedaan dalam masyarakat, sehingga tercipta masyarakat multietnik Kalbar yang hidup damai dan harmonis. Dalam buku mulok untuk kelas IX dibahas secara khusus mengenai sistem perladangan, aneka bahasa daerah dan adat kematian yang berlaku untuk etnik-etnik yang ada di Kalbar. Materi yang menarik pada buku ini adalah pembahasan mengenai sejarah bahasa yang dimiliki oleh beragam etnik yang ada di Kalbar. Tentu saja pengetahuan ini bisa membantu siswa dalam proses berinteraksi, sekaligus menjadi kekayaan dalam berkomunikasi agar mereka bisa diterima dalam lingkungan masyarakat. Pengenalan akan dialek dan logat bahasa yang terdapat di berbagai etnik di Kalbar dapat mempermudah siswa mengenal latar belakang orang lain dari 
cara bertuturnya.

Penulis juga menemukan adanya narasi-narasi yang memuat informasi mengenai konflik antaretnis di Kalbar yang bersumber dari berbagai media cetak dan berita yang diterbitkan oleh Komnas HAM. Semuanya disajikan dengan tujuan agar peserta didik bisa saling mengingatkan, menjaga, merawat, dan menghormati keberagaman yang ada di Kalbar.

\section{Implementasi Pendidikan Multikultur di Kalbar}

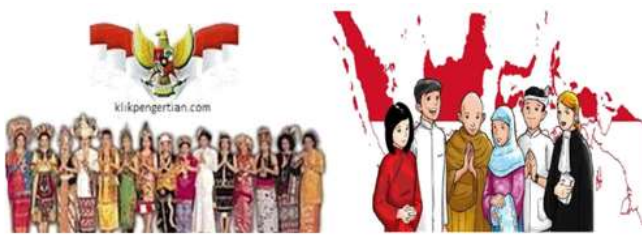

Gambar 4. Makna dan Arti Bhinneka Tunggal Ika Sumber: https://www.bospedia.com, diakses 27 Maret 2018.

Dalam tataran implementasi, masing-masing siswa dari setiap kelas akan mengadakan kegiatan yang praktis bersama dengan teman-temannya. Kegiatan tersebut dilakukan di lingkungan sekolah, keluarga dan masyarakat. Contoh-contoh implementasi yang diuraikan di dalam buku mulok ini dipraktikkan dan dialami oleh siswa secara langsung. Hal inilah yang menjadi salah salah satu kekuatan dari proses pendidikan multikultur di sekolah.

\subsection{Contoh Implementasi di Kelas VII}

Di kelas VII, siswa diminta untuk melaksanakan tugas pembelajaran, baik perorangan maupun kelompok. Penulis mengambil salah satu contoh dari tugas perorangan yang bertujuan untuk mengarahkan siswa supaya mereka dapat menemukan sendiri pengalaman dan pengetahuan secara konkret dari kehidupan sehari-hari. Misalnya, membuat karangan tentang pengalaman pribadi dalam berteman ataupun bergaul dengan teman-teman atau orang-orang yang berada di lingkungan tempat tinggalnya (Petebang et al., 2008: 14). Sedangkan contoh penugasan kelompok adalah bersama dengan teman-temannya membuat kliping dari berbagai media massa, baik cetak maupun elektronik, yang bertema praktik-praktik adat istiadat, budaya dan agama dari etnis Madura, Dayak, Melayu dan Tionghoa di Kalbar. Setelah terkumpul siswa memaknai nilai-nilai perdamaian dari masing-masing adat istiadat, budaya, budaya, dan agama tersebut. Jadi, melalui tugas ini guru dapat menginternalisasikan nilai kerja sama dan pentingnya persatuan dalam mencapai tujuan bersama, sehingga tercipta keharmonisan hidup di antara mereka, baik di lingkungan sekolah maupun masyarakat.

Di dalam buku mulok pendidikan multikultur tersebut ditemukan juga pembicaraan mengenai gambaran tentang kondisi masyarakat Kalbar yang multietnik dan relasi antarkelompok yang memiliki perbedaan etnik tersebut. 
Dengan demikian bila di sekolah terjadi ketegangan dalam proses interaksi antarsiswa yang berbeda latar belakang etniknya, mereka diharapkan sudah bisa saling memahami, menghormati, dan menerima perbedaan itu sebagai realitas kehidupan dalam kemajemukan di Kalbar.

Di masyarakat Kalbar yang terdiri atas bermacam perbedaan tersebut terjadi hubungan timbal balik yang saling menguntungkan. Masing-masing tidak bisa hidup sendirian karena saling membutuhkan. Semua etnik yang ada di Kalbar sesungguhnya bersikap terbuka terhadap etnik lainnya. Ini bisa dilihat dari filosofi orang Dayak yang berbunyi "ahe gik talino, asu' pun dibare makantn" (jangankan manusia, anjing pun diberi makan). Dalam peribahasa bahasa Melayu dikenal adanya pernyataan "kecik telapak tangan, nyiru kamek tadakan" (menerima orang dengan leluasa, tanpa batasan etnis, agama, warna kulit dan lainnya). Sedangkan dalam masyarakat Madura dikenal adanya pepatah, "oreng daddi taretan", artinya orang lain yang tidak punya hubungan apa-apa akan diperlakukan layaknya saudara sendiri (Petebang et al., 2008: 46).

Siswa Kelas VII juga ditugaskan untuk menulis silsilah keluarganya berdasarkan etnik, mulai dari buyut, kakek/nenek, ayah/ibu, paman/bibi dari ayah dan paman/bibi dari ibu. Di sini siswa mau tidak mau akan langsung berkomunikasi dengan keluarga untuk menanyakan sisilah keluarganya. Penyadaran akan dirinya sebagai salah satu bagian dari etnik tertentu membuat siswa menerima dengan rasa bangga akan kehadiran dirinya baik di sekolah, keluarga maupun di lingkungan masyarakat sehari-hari. Siswa kemudian bisa menceritakan asal-usul sukunya kepada siapa saja, misalnya melalui interaksi di dalam kelas, sehingga proses ini akan menjadi praktik dari metode sharing sebagai kekuatan dalam pendidikan multikultur itu sendiri.

Di kesempatan lain siswa membentuk kelompok yang terdiri dari 5-10 orang. Tidak ada pemisahan gender dan latar belakang etnik, sehingga di setiap kelompok terdiri dari laki-laki dan perempuan, serta beragam etnik. Pada bagian ini siswa mendata penduduk di sekitar tempat tinggal mereka secara berkelompok, misalnya tentang jumlah penduduk, bahasa yang digunakan, budaya yang berlaku, kesenian yang dikenal, sesuai dengan etnik dan jumlah etnik yang ada di sekitar tempat tinggal mereka. Data ini sangat membantu mereka mendapatkan wawasan baru mengenai kondisi masyarakat. Pada bagian tertentu mereka diminta untuk membuat miniatur rumah adat salah satu etnik yang ada di Kalbar (Petebang et al., 2008: 47).

\subsection{Contoh Implementasi di Kelas VIII}

Penulis menemukan peserta didik di kelas VIII diberi pengetahuan tentang peristiwa kelahiran adiknya ataupun orang-orang lain yang berasal dari 
beragam etnik. Pengenalan tersebut dilakukan melalui penugasan yang diberikan kepada siswa. Mereka diminta untuk membuat tulisan yang berisi tentang urutan upacara adat atau tradisi selama proses kelahiran yang terjadi di keluarga atau tetangganya. Mereka harus mempelajari tahapan dalam proses kelahiran yang berlaku pada budaya tertentu tersebut, mulai dari tahap persiapan, saat melahirkan, hingga bayi berusia satu tahun. Siswa juga ditugaskan untuk mengumpulkan foto-foto yang menggambarkan upacara adat kelahiran itu (Petebang et al., 2011: 28).

Di proses pembelajaran lainnya, siswa ditugaskan untuk menulis karangan tentang ritual adat dan tradisi yang masih dilakukan oleh orang tua atau keluarga, misalnya yang dilakukan dalam upacara perkawinan (Petebang et al., 2011: 61). Contoh implementasi yang lain adalah menugaskan siswa untuk membuat salah satu benda seni yang mewakili kelompok etnik tertentu di Kalbar. Misalnya, perisai, patung, hiasan bermotif Dayak (kebudayaan Dayak); ataupun tambur, perahu lancang kuning, pantun (kebudayaan Melayu). Intinya, melalui berbagai penugasan ini siswa diperkenalkan dengan kebudayaan yang berasal dari berbagai etnik yang ada di Kalbar.

\subsection{Contoh Implementasi di Kelas IX}

Pada buku Mulok Pendidikan Multikultur Kalimantan Barat untuk SMP/MTs Kelas IX, terdapat contoh implementasi yang menarik bagi penulis saat siswa diperkenalkan dengan berbagai bahasa daerah/ kelompok etnik tertentu. Siswa bukan hanya mempelajari bahasa Dayak, Melayu, Tionghoa, dan Madura, melainkan belajar pula bahasa dari suku-suku lain, seperti: Batak, Sunda, Bugis, dan NTT. Tentu saja dengan bekal pengetahuan tentang beragam bahasa ini, siswa kelas IX semakin berani untuk bersosialisasi dengan beraneka ragam etnik yang memiliki gaya bahasanya masing-masing.

Buku untuk kelas IX ini mengarahkan siswa untuk mengimplementasikan pembelajaran beragam bahasa daerah/kelompok etnik tertentu secara berkelompok dengan cara membuat kamus bahasa daerah/ kelompok etnik tersebut, minimal 100 kata. Misalnya, kelompok I membuat kamus bahasa Tionghoa Hakka; kelompok II membuat kamus bahasa Madura, dan seterusnya (Petebang et al. 2011: 25).

Penulis juga dapat menemukan adanya proses penanaman nilai-nilai mutikulturalisme terhadap peserta didik. Nilai-nilai diajarkan kepada siswa melalui praktik langsung dengan mengarahkan siswa untuk menunjukkan perilaku menghormati, menjaga, dan merawat alam di sekitarnya. Dalam hal ini aspek sosiokultur pada etnik tertentu, misalnya Dayak, disampaikan melalui pengenalan tentang tata cara berladang yang mengikuti urutan dan aturan tertentu yang tidak boleh dilakukan 
secara sembarangan. Perwujudannya adalah masing-masing siswa membuat tulisan tentang proses perladangan, mulai dari mencari lahan untuk berladang sampai upacara setelah panen (Petebang et al. 2011: 37). Selain mengenal sistem perladangan pada masyarakat Dayak, siswa juga diajak untuk mengenal upacara kematian yang terdapat pada beragam kelompok etnik melalui penugasan membuat tulisan singkat yang berisi urutan upacara kematian yang pernah mereka lihat di Kalbar (Petebang et al. 2011: 65).

Tiga buku Mulok Pendidikan Multikultur, yakni yang diperuntukkan bagi siswa di kelas VII, VIII dan IX ini, menunjukkan bahwa implementasi pendidikan multikultur tidak melulu berada pada sisi kognitif saja, tetapi juga mengandung aspek afektif, psikomotorik, dan sosial. Dengan demikian proses pembelajaran di sekolah dapat membangun spirit kebersamaan, sehingga tercipta benihbenih yang dapat menumbuhkan harmonisasi di antara siswa di suatu sekolah. Lebih jauh lagi, penghayatan nilai-nilai yang didapatkan di sekolah melalui pendidikan multikultur ini diharapkan dapat terimplementasi dalam relasi sosial yang melibatkan siswa secara langsung dengan warga yang ada di lingkungan masyarakat Kalbar yang terdiri dari beragam etnik.

\section{PENUTUP}

Berangkat dari rumusan masalah yang disajikan di awal tulisan ini, ada dua simpulan dari penulis yang diperoleh dari tulisan ini. Pertama, penulis mempelajari dan menganalisis isi buku muatan lokal pendidikan multikultur yang diterapkan di tujuh SMP/MTs di Kota Pontianak. Buku tersebut sungguh-sungguh memuat gambaran tentang beragam etnik yang ada di Kalbar dan nilai-nilai penting yang terdapat dalam wacana multikulturalisme. Etnik-etnik itu antara lain: Melayu, Tionghoa, Dayak, Madura, Bugis dan etnik lain yang ada di Kalbar. Materi-materi yang diajarkan kepada siswa berbicara mengenai keanekaragaman etnik dan kebudayaan yang dimiliki oleh masingmasing kelompok etnik tersebut, seperti yang terlihat dari bahasa, kesenian, makanan, serta adat istiadatnya. Melalui pembahasan tiap materi yang ada di buku-buku tersebut, peserta didik diharapkan dapat menjaga, merawat, dan menghormati perbedaan yang ada dalam bingkai persaudaran yang harmonis dengan siswa ataupun orang lain yang hidup di sekitarnya.

Kedua, implementasi nilai-nilai multikulturalisme dari muatan lokal yang dilakukan di setiap akhir penyampaian materi pelajaran. Peserta didik diajak untuk melakukan aktivitas bersama yang bertujuan untuk memperkenalkan keaneragaman budaya dari berbagai etnik di Kalbar. Melalui penugasan mandiri dan kelompok, diskusi bersama, dan praktik lapangan, nilai-nilai tersebut dapat dintenternalisasikan sehingga membantu siswa untuk bisa menghayati pola-pola relasi dengan teman-teman 
di sekolah, keluarga dan lingkungan masyarakat Pontianak. Buku Mulok Pendidikan Multikultur Kalimantan Barat untuk SMP/MTs ini mengandung sejumlah nilai yang bermanfaat dalam proses tumbuh kembang siswa. Nilainilai tersebut mengandung lima aspek yang penting, yaitu kognitif, afektif, psikomotorik, sosial, dan spiritual.

Akhirnya, rangkaian kegiatan pembelajaran yang dilakukan dalam mulok pendidikan multikulturalisme ini diharapkan mampu mendorong transformasi sosial di sekolah dan masyarakat, sehingga tercipta hidup yang harmonis di Kota Pontianak dalam bingkai keaneragaman masyarakatnya.

Dari pembahasan di atas, ada beberapa rekomendasi yang penulis ajukan. Rekomendasi ini memuat beberapa hal yang belum muncul dan diharapkan dapat menguatkan implementasi pendidikan multikultur. Rekomendasi dari penulis adalah perlunya latihan/ praktik nyata yang membuat siswa dapat mengembangkan sikap penerimaan terhadap orang lain yang berbeda. Kegiatan-kegiatan yang dapat menumbuhkan sikap tersebut, antara lain (a) Live in di lingkungan yang berbeda agama, budaya, status sosial, dan sebagainya. (b) Kelompok kelas perlu selalu ditata secara khusus, sehingga siswa yang berada di kelompok tersebut merupakan kumpulan siswa yang berbeda latar belakang sosial dan budayanya. Pihak sekolah dan guru dapat mengondisikan kelas, tempat duduk, dan pembagian kelompok tugas belajar atau proyek agar selalu terdiri dari kumpulan siswa yang berbeda agama, etnis, budaya, dan status sosial. Jika siswa terbiasa dicampur dan ternyata mereka mengalami bahwa pencampuran itu sungguh membantu mereka, maka siswa diharapkan akan mengembangkan sikap menghargai orang lain. (c) Menghadirkan pembicara dan teman dari sekolah lain yang berbeda situasinya. Hal ini juga dapat membantu siswa lebih mudah menerima perbedaan itu. (d) Mengadakan perlombaan olahraga dan seni dengan sekolah yang berbeda etnis, budaya, agama, dan sebagainya. Misalnya, antara sekolah negeri, Islam, Katolik, Kristen, Taman Siswa, nasional, dan sebagainya.

Rekomendasi lain terkait pengkajian pendidikan multikultur, menimbang keterbatasan penulis dalam penelitian ini. Pertama, penulis masih fokus pada narasi-narasi konflik yang bersumber pada media cetak sehingga mengalami keterbatasan untuk menarik sebuah simpulan yang akurat dan realistis. Padahal, kajian akan semakin baik, jika penulis menghadirkan kritik dari media yang mempelajari konflik di Pontianak. Kedua, belum menampilkan kekhasan foto-foto yang dapat merespresetasikan implementasi pendidikan multikultur di Kota Pontianak.

Rekomendasi lain berupa saran untuk pemerintah, baik pusat maupun daerah sebagai berikut. 1) Pemerintah perlu segera menangkap isyarat dari gerakan sosial yang muncul karena keprihatinan akan pertikaian sosial yang 
menimbulkan luka batin yang sangat parah di antara kelompok yang bertikai. Luka itu tidak akan bisa disembuhkan dalam waktu sekejap, bahkan dapat menimbulkan rasa dendam, kebencian, sikap saling curiga, dan sejenisnya. Sikap demikian tentu saja menjadi bara api yang sewaktu-waktu dapat membakar ketenangan dan ketentraman dalam kehidupan bermasyarakat. Dengan demikian, rekonsiliasi yang dilakukan tidak sekedar pernyataan tertulis tetapi harus disertai kesadaraan dari hati yang terdalam dan komitmen untuk mengubah perilaku yang kurang sesuai, misalnya menghapus budaya kekerasan baik secara ideologi, fisik yang terencana maupun bersifat spontan. Perilaku negatif tersebut tidak bisa dibiarkan untuk terus berkembang di dalam tatanan masyarakat yang multikultur. 2) Pemerintah dapat menerapkan mulok pendidikan multikultur, sebagai strategi mencegah konflik sosial yang selama ini berbenturan dengan berbagai kepentingan di dalam pendidikan itu sendiri. Buku-buku yang dikaji dalam tulisan ini sangat cocok pula untuk diterapkan di sekolah-sekolah dengan peserta didik yang memiliki keberagaman latar belakang.

\section{DAFTAR SUMBER}

Ali, Muhamad. 2003. PluralisMultikulturalis. Jakarta: Kompas.

Abdilah, S., Ubed. 2002. Politik Identitas Etnis: Pergulatan Tanda
Tanpa Identitas. Magelang: Indonesiatera.

Baker G.C. 1994. Planning and Organizing for Multicultural Instruction. (2nd). California: AddisonElsey Publishing Company.

Darmawan, Josep J. (ed.) 2005 . Multikulturalisme Membangun Harmoni Masyarakat Plural. Yogyakarta: Universitas Atma Jaya.

Delphina, Hopkins. Gillispie. 2011. Curriculum \& Schooling: Multiculturalism, Critical Multiculturalism and Critical Pedagogy. The South Shore Journal Vol. 4.

Giring. 2003. Madura di Mata Dayak dari Konflik ke Rekonsiliasi. Yogyakarta: Galang Press.

Herlambang, W. 2013. Kekerasan Budaya Pasca 1965. Jakarta: CV. Marjin Kiri.

https://www.kbbi.web.id, diakses pada 27 Maret 2018.

https://www.bospedia.com, diakses pada 27 Maret 2018.

Kristiyanto, Eddy A, dan William Chang (ed.). 2014. Multikuturalisme: Kekayaan dan Tantangan di Indonesia. Jakarta: Obor. 
Parekh. Bhiku. 2008. Rethinking Multiculturalism-Keberagaman Budaya dan Teori Politik. Yogyakarta: Kanisius.

Petebang V. Edi et al. 2008. Muatan Lokal Pendidikan Multikultur Kalimantan Barat Kelas VII. Pontianak: Institut DayakologiAliansi untuk Perdamaian dan Rekonsiliasi (ANPRI). 2011. Muatan

Lokal Pendidikan Multikultur Kalimantan Barat Kelas VIII. Pontianak: Institut DayakologiAliansi untuk Perdamaian dan Rekonsiliasi (ANPRI). 2011. Muatan Lokal Pendidikan Multikultur Kalimantan Barat Kelas IX. Pontianak: Institut DayakologiAliansi untuk Perdamaian dan Rekonsiliasi (ANPRI).

Sastraprajatedja, M. 2013. Pendidikan sebagai Humanisasi. Jakarta: Pusat Kajian Filsafat \& Pancasila.

Situmorang, Nurartha (ed.). 1999. Sisi Gelap Kalimantan BaratPeseteruan Etnis Dayak- Madura 1997. Pontianak: Midas Surya Grafindo.

Siegel, T. James. 2000. Penjahat Gaya Orde Baru, Eksplorasi Politik dan Kriminalitas tentang PikiranPikiran Awal Kekerasan 13 dan 14
Mei 1998. Yogyakarta: LKIS.

Sudagung, H. Suroyo. 2001. Mengurai Pertikaian Etnis, Migrasi Swarkarsa Etnis Madura ke Kalimantan Barat. Yogyakarta: Institut Studi Arus Informasi.

Sudiarja. A. 2014. Pendidikan dalam Tantangan Zaman.Yogyakarta: Kanisius.

Suparno, Paul. 2015. Pendidikan Karakter di Sekolah. Yogyakarta: Kanisius.

Tanuhandaru, Protus (ed.). 2008. Tionghoa Dalam Cengkerama SBKRI. Jakarta: Visimedia.

Tilaar, H.A.R. 2004. Multikulturalisme; Tantangan-Tantangan Global Masa Depan Dalam Transformasi Pendidikan Nasional. Jakarta: Grasindo.

Yaya, Suryana, H.A. Rusdiana. 2015. Pendidikan Multikultural: Suatu Upaya Penguatan Jati Diri Bangsa. Bandung: Pustaka Setia. 